\title{
Health Care Students' Attitudes towards People with Schizophrenia- A Survey of Eight University Training Programs
}

\author{
Bengt Svensson"1, David Brunt ${ }^{2}$, Ulrika Bejerholm1, Mona Eklund1, \\ Amanda Lundvik Gyllensten', Christel Leufstadius', Urban Markström³, \\ Mikael Sandlund4, Margareta Östman5, Lars Hansson'1 \\ ${ }^{1}$ Department of Health Sciences, Lund University, Lund, Sweden \\ ${ }^{2}$ School of Health Sciences and Social Work, Linnean University, Växjö, Sweden \\ ${ }^{3}$ Department of Social Work, Umeå University, Umeå, Sweden \\ ${ }^{4}$ Department of Clinical Sciences/Psychiatry, Umeå University, Umeå, Sweden \\ ${ }^{5}$ Faculty of Health and Society, Malmö University, Malmö, Sweden \\ Email: bengt.svensson@med.lu.se
}

Received 11 July 2014; revised 6 August 2014; accepted 5 September 2014

Copyright (C) 2014 by authors and Scientific Research Publishing Inc.

This work is licensed under the Creative Commons Attribution International License (CC BY). http://creativecommons.org/licenses/by/4.0/

c. (i) Open Access

\begin{abstract}
Background: Discrimination and stigmatization of people with mental illness are a global and complex phenomenon and there is evidence that negative attitudes and discrimination are also prevalent among health care staff and health care students. Methods: Attitudes towards people with schizophrenia among 1101 students in eight different university programs providing training for work in the health care and social sectors were explored, using a cross-sectional design. Results: In five of the eight training programs the majority of the students' perceived people with schizophrenia as a danger to others. In several aspects police students were found to hold more negative attitudes than students from other programs. Students with previous experiences of work in mental health services and students knowing a person with schizophrenia showed more positive attitudes. Discussion: In order to decrease negative attitudes and prejudices towards people with schizophrenia among students, it is essential that the training includes personal contact with people with experience of being mental illness.
\end{abstract}

\section{Keywords}

Attitudes, Stigma, Schizophrenia, Students

How to cite this paper: Svensson, B., Brunt, D., Bejerholm, U., Eklund, M., Gyllensten, A.L., Leufstadius, C., Markström, U., Sandlund, M., Östman, M. and Hansson, L. (2014) Health Care Students' Attitudes towards People with Schizophrenia-A Survey of Eight University Training Programs. Open Journal of Psychiatry, 4, 309-316. 


\section{Introduction}

Discrimination and stigmatization of people with mental illness are a global and complex phenomenon linked to problems of knowledge, attitudes and behaviour [1]. Negative attitudes, stereotypes and discrimination are still highly prevalent in the population [2]. In fact there is evidence that public attitudes have not changed during the last two decades, or even turned worse in the case of people with schizophrenia [3]. Stigma and discrimination in many ways affect people with a mental illness causing a lowered self-esteem and quality of life [4], and affecting possibilities of adequate housing, work and financial situation in a negative way [5] [6]. Stigma is also a major barrier to help seeking [7] and cause delays, dropout and non-adherence in treatment [8] [9]. Recurrent studies during the last decades in the general population have further shown that people with mental illness are perceived as strange, frightening, unpredictable, aggressive and lacking self-control. Particularly people with schizophrenia are associated with negative stereotypes [10]-[12]. In repeated studies schizophrenia has been identified as the most stigmatizing condition among all types of mental illness [13] [14], closely linked to perceptions of fear, violence and being unpredictable.

Although stigmatizing attitudes is prominent among the general population it could be expected that professionals within the health care system would have a more knowledge-based, reflected and realistic view of persons with mental health problems. However, there is evidence that people with mental illness feel patronised, humiliated and punished in contact with services and that patients point out mental health staff as one of the groups which are the most stigmatizing [1]. Studies on mental health staff's attitudes have mainly focused on the prevalence of stereotypes and desire for social distance from people with mental illness. A review of studies focusing attitudes of mental health staff revealed that a majority of these studies constituted comparisons between staff and the general population [15]. One of the main findings from this review is that a majority of the studies show that beliefs of mental health providers do not differ from the general population or are more negative. This is in contradiction with a hypothesis that professionals' knowledge of mental illness and regular contact with people with a mental illness would result in more favourable attitudes. However it seems that this does not act as a protective factor when it comes to the prevalence of stereotypes regarding people with a mental illness or a greater willingness to interact with these people [16] [17]. A Swedish study not included in this review showed that attitudes towards mental illness and people with mental illness among nursing staff in psychiatric and somatic health care were similar [18]. Related studies from somatic health care also illustrate the phenomenon of diagnostic overshadowing. Persons with mental health problems report experiences of being treated with disrespect, being ignored, and being subjected to the suspicion that their physical complaints may be related to their mental illness [19]-[21].

Students' attitudes toward schizophrenia have only been scarcely studied, although a few studies have been presented. A study in Germany with focus on teenagers in secondary and grammar school showed that only a few students actually endorsed negative views about people with schizophrenia [22]. Another study of teenager's attitudes however presented quite high percentages of students who had stigmatizing attitudes and a desire for social distance [23]. In a study comparing stigmatization of schizophrenia as perceived by nurses, medical doctors, medical students and patients it was found that medical students reported the highest level of stigmatizing attitudes including assumptions of dangerousness, unpredictability and a desire for social distance [24]. On the other hand Linden and Kavanagh [25] did not find any significant differences, when comparing attitudes toward persons with schizophrenia, between registered mental health nurses and mental health nurse students. A study of pharmacy students revealed that a large majority of the participants would be unwilling to share a flat with a person with a diagnosis of schizophrenia ask such a person to be baby sitter. In the same study a majority also believed that people with schizophrenia are unpredictable and dangerous [26]. The results of studies of student's attitudes are so far inconclusive and performed in different cultural contexts that might be of importance. In the context of the negative attitudes from different groups in society towards persons with mental illness, it is important to investigate and to understand the attitudes held by those university students, who are preparing for work in the health care and adjacent fields, and who will bring these attitudes into their chosen profession. No theories have to our knowledge been presented concerning the differences in attitudes and intentional behaviour between student groups and an explorative study might shed more light on this field.

\section{Aims}

The aim of the present study was to investigate attitudes towards people with schizophrenia among students in 
eight different university programs providing training for work in the health care and social sectors.

Further research questions were: do attitudes towards people with schizophrenia differ with regard to type of university program, the students' sex, age, living conditions, familiarity with mental illness or past experience of work in the mental health sector? Our hypothesis was that students having a familiarity with people with schizophrenia would show more positive attitudes.

\section{Methods and Subjects}

This study is part of a research project aiming at investigating attitudes towards mental illness among different categories of university students. A sample of students in training for a broad range of health professions, not yet in the part of their training that focused on psychiatry and mental illness was aimed for. Thus, universities with training programs for nurses, occupational therapists, physiotherapists, physicians, psychologists, public health workers and social workers were approached. The selection of student categories was based on the strategic reasoning that these form the vast majority of professional categories working with health care and support for people with mental illnesses. Furthermore, since we aimed at participation also from other professions in regular contact with people with mental illness, training programs for police officers were approached as well. Universities from all over Sweden were approached and asked for participation, and strategic sampling was used in order to obtain heterogeneity. The principles utilized in the sampling process were also those of age and size of the university and their geographical distribution in the country. Six universities were initially selected, four agreed to participate and two declined due to bad timing. A further two universities were approached and both were willing to participate, and by these measures the variations in the sample needed was reached. This study complied with stipulations in the Swedish Act Ethical Review of Research Involving Humans (SFS, 2003), and informed consent was applied.

\subsection{Procedure}

The procedure for selection of subjects was the same at all universities. A member of the research team made contact with a teacher working with the targeted student group. The teacher asked for the students' informed consent and explained that participation was voluntary. The teacher scheduled the data collection, which was timed to occur prior to but close to a course that focused on mental illness in each programme or a more comprehensive course where mental illness formed a part. The contact teacher distributed the instrument to the students at the beginning of an ordinary lecture. The instruments were completed immediately and the responses were placed in a box, which was subsequently collected or sent to the research team. Information about the exact number of dropouts is uncertain due to the procedure used. Comparisons of the number of students enrolled for the courses with the number of participating students showed, however, that the number of dropouts was fairly low.

\subsection{Measures}

Level of familiarity with people with mental illness was elicited by using a slightly modified version of the Level of Familiarity Questionnaire [27]. The questionnaire contains 11 statements about familiarity with mental illness. Answer on each statement is yes or no. If more than one statement is affirmative, the highest level of familiarity is used for ranking. The highest rank is $11=$ high familiarity with a person with mental illness, 7 = medium familiarity, 1 = little familiarity.

In order to investigate opinions about persons with schizophrenia, a Swedish version of the Attitudes to Persons with Mental Illness questionnaire was used [10]. In the first part of the questionnaire questions about familiarity with specific mental illness are requested. The following part of the questionnaire elicits attitudes towards seven different mental illnesses: severe depression, panic attacks, schizophrenia, dementia, eating disorders, alcohol addiction and drug addiction. For each mental illness eight statements are included where the respondent can choose to answer on a five-point scale including extreme statements, for example " 1 = not dangerous to others, 5 = dangerous to others". A high rating always indicate a more stigmatizing attitude A study of the psychometric properties of the Swedish version revealed dubious test-retest reliability for some of the disorders and attitudes items [28]. Thus, in this study, only attitudes towards schizophrenia were analyzed and the statements regarding "unpredictable" and "difficult to talk with" were excluded. If the students marked one of the two answer alternatives on the negative side of the five-point scale they were regarded as having a "negative 
attitude”.

In addition information about sociodemographic characteristics was obtained.

\subsection{Statistics}

Pearson product-moment correlation was used to investigate associations between variables.

Student's t-test was used to analyze relationships of attitudes to socio-demographic variables where the variable had two categories (e.g. sex). One-way analysis of variance with Scheffe's post-hoc test was used to test for differences in attitudes between students in different educational programs. The statistical software package used was SPSS 20.0 for Windows. The Alpha level was set to $<0.05$.

\section{Results}

Table 1 shows the number of participants in the study, divided in type of training programs and sociodemographic characteristics. A majority of students were female (75\%) and the three most common student groups were social worker, nurse and police students comprising $68 \%$ of the participants. A minority (35\%) had experiences of previous work with people with mental illness and the length of work experience in mental health services varied greatly (1 month - 20 years).

Attitudes among students in different education programs showed that irrespective of program a great majority of the student's perceived people with schizophrenia as unusual (Table 2). In five of eight education programs a majority of the students perceived people with schizophrenia as a danger to others, and with regard to prospects of recovery more than a third of the students in seven of eight education programs were pessimistic about the possibilities to recover from schizophrenia. Differences between the educational programs were few. Police students were more negative than nurse students, social work students, occupational therapist students and physiotherapist students in three of the items and physiotherapist students had more negative attitudes than

Table 1. Sociodemographic characteristics of the sample $(n=1101)$.

\begin{tabular}{|c|c|}
\hline Variable & n (\%) \\
\hline $\begin{array}{c}\text { Sex }(\mathrm{n}=1100) \\
\text { Male } \\
\text { Female }\end{array}$ & $\begin{array}{l}269(24.5) \\
831(75.4)\end{array}$ \\
\hline Age md (range) $(n=1096)$ & $25(19-53)$ \\
\hline $\begin{array}{l}\text { Civil status }(\mathrm{n}=1090) \\
\text { Married/cohabiting } \\
\text { Alone }\end{array}$ & $\begin{array}{l}571(52.4) \\
518(47.6)\end{array}$ \\
\hline \multicolumn{2}{|l|}{ Student groups } \\
\hline Nurse students & $210(19.1)$ \\
\hline Police students & $203(18.4)$ \\
\hline Social work students & $342(31.1)$ \\
\hline Occupational therapist students & $95(8.6)$ \\
\hline Physiotherapist students & $81(7.4)$ \\
\hline Physician students & $78(7.1)$ \\
\hline Psychologist students & $62(5.6)$ \\
\hline Public health students & $30(2.7)$ \\
\hline Familiarity md (range) $(\mathrm{n}=961)$ & $7(0-11)$ \\
\hline \multicolumn{2}{|l|}{ Experiences of previous work in mental health services $(n=1088)$} \\
\hline Yes & $376(34.6)$ \\
\hline No & $711(65.4)$ \\
\hline Length of work in mental health services (months) md (range) & $8.0(1-239)$ \\
\hline
\end{tabular}


nursing students and social work students concerning the aspect of "pulling themselves together" (Table 3).

The influence of sociodemographic factors on attitudes to persons with schizophrenia revealed that a larger percentage of male students $(\mathrm{n}=269)$ stated that persons with schizophrenia have themselves to blame for their disorder (1.5 \pm 0.8 vs. $1.3 \pm 0.6 ; \mathrm{p}=0.001)$ while female students $(\mathrm{n}=831)$ to a higher degree perceived persons with schizophrenia as "unusual" ( $4.4 \pm 1.0$ vs $4.1 \pm 1.2$; $\mathrm{p}=0.001)$. Younger students had to a higher degree the perception that persons with schizophrenia have themselves to blame for their disorder $r=-0.06(p=0.05)$ and that they are unpredictable $r=-0.17(\mathrm{p}=0.01)$.

A larger proportion of students living alone perceived persons with schizophrenia as more unpredictable than students who were married or cohabiting $(4.3 \pm 0.7$ vs $4.1 \pm 0.8$; $\mathrm{p}=0.005)$ and students with experience of work in mental health services $(n=377)$ perceived persons with schizophrenia as less dangerous $(3.5 \pm 1.1$ vs $3.6 \pm 0.9 ; \mathrm{p}=0.01)$ than students with no such experience $(\mathrm{n}=710)$.

Students who claimed that they knew a person with schizophrenia $(n=131)$ perceived persons with the disorder as less dangerous ( $3.3 \pm 1.1$ vs $3.6 \pm 0.9$; $\mathrm{p}=0.003$ ), and were more optimistic about improvement if treated $(1.8 \pm 0.9$ vs $2.1 \pm 0.9 ; \mathrm{p}=0.003)$. When comparing this group with those who had work experience of mental health no significant differences were found.

\section{Discussion}

Negative attitudes and prejudices towards people suffering from mental illness is an important obstacle for inclusion and participation on equal conditions into the society. In the present study we asked students, whose future occupation would be in the social and health care fields about how they perceived people suffering from schizophrenia, being as they are part of one of the most exposed subgroups of people with mental illness. The rather large sample representing eight different university programs with a nation wide coverage must be considered as a fairly representative sample. That the sample also consisted of mostly female participants is also a strength since the distribution of sex reflects the labour situation with regard to the student's future professions.

Table 2. Attitudes to people with schizophrenia among students divided in different education program $(\mathrm{n}=1101)(\%)^{*}$.

\begin{tabular}{|c|c|c|c|c|c|c|}
\hline Student groups & $\begin{array}{c}\text { Danger to } \\
\text { others }\end{array}$ & $\begin{array}{c}\text { Themselves to } \\
\text { blame }\end{array}$ & $\begin{array}{l}\text { Not improved if } \\
\text { treated }\end{array}$ & $\begin{array}{l}\text { Perceived as } \\
\text { unusual }\end{array}$ & $\begin{array}{l}\text { Pulling themselves } \\
\text { together }\end{array}$ & Never recover \\
\hline Nurse students & 42 & 1 & 5 & 54 & 2 & 30 \\
\hline Police students & 69 & 2 & 9 & 75 & 2 & 34 \\
\hline Social work students & 55 & 1 & 11 & 76 & 4 & 40 \\
\hline $\begin{array}{l}\text { Occupational therapist } \\
\text { students }\end{array}$ & 50 & 1 & 6 & 84 & 6 & 33 \\
\hline $\begin{array}{l}\text { Physiotherapist } \\
\text { students }\end{array}$ & 54 & 3 & 1 & 77 & 6 & 26 \\
\hline Physician students & 46 & 1 & 4 & 90 & 5 & 42 \\
\hline Psychologist students & 44 & 1 & 10 & 86 & 1 & 55 \\
\hline Public health students & 60 & 1 & 20 & 70 & 13 & 47 \\
\hline
\end{tabular}

"If the students marked one of the two answer alternatives on the negative side of the five-point scale they were regarded as having a "negative attitude”.

Table 3. Significant differences in attitudes between students in the different programs $(\mathrm{n}=1101)$. The numbers in the cells indicate which item the difference concern. See text below the table.

\begin{tabular}{cccc}
\hline Student group & Nurse students & Social work students & Occupational therapist students \\
\hline Police students & $2^{* *}$ & $2^{* *}$ & $1^{*}$ \\
Physiotherapist students & $5^{* *}$ & $5^{* *}$ & n.s \\
\hline
\end{tabular}

1. Danger to others; 2. Themselves to blame; 3. Not improved if treated; 4. Perceived as unusual; 5 . Pulling themselves together; 6 . Never recover. One-way Anova, ${ }^{*} \mathrm{p}<0.05,{ }^{* *} \mathrm{p}<0.01,{ }^{* * * *} \mathrm{p}<0.001$. Programs in left column (police students and physiotherapy students) showing more negative attitudes. 
In five of the eight education programs the majority of the students perceived people with schizophrenia as a danger to others, and with regard to prospects of recovery more than a third of the students in seven of the eight education programs were pessimistic about prospects of recovery from this disorder. These results present a picture of a rather negative apprehension of people suffering from schizophrenia, but at the same time they are in accordance with the findings in studies by Björkman et al. [18] and Crisp et al. [10] who found negative perceptions about persons with schizophrenia among nursing staff and the general population, respectively.

With regard to variations between the education programs, police students in several aspects seem to hold more negative attitudes than students from other training programs. A plausible interpretation may be that police students to a greater extent during their university education are trained in handling difficult situations where security has a higher priority, rather than training how to treat persons with schizophrenia. Studies among police officers about attitudes towards people suffering form mental illness partly support these findings. Watson et al. [29] found that a label associated with schizophrenia increased perceived dangerousness among police officers. However, studies among police officers are rare and it is not evident that police officers hold more negative attitudes towards people with mental illness than the general population [30].

Our hypothesis that greater familiarity with people with schizophrenia will contribute to less negative attitudes was confirmed. Students with experience of past work in mental health service and students knowing a person with schizophrenia showed less negative attitudes compared to those without such work experience or such personal knowledge. This finding is in line with earlier studies which found that personal contact with people suffering from mental illness contribute to less negative attitudes [27] [31]. This could be made through cooperation with consumer organizations. To invite consumers to give lectures or to participate in discussion groups could easily be included in course curriculums.

\section{Conclusion}

In summary, attitudes among students towards people with schizophrenia are in several instances comparable with attitudes as presented by the general population. In order to decrease negative attitudes and prejudices towards people with schizophrenia among students it is essential that the training includes personal contact with people with experiences of being mentally ill.

\section{Acknowledgements}

The study was financially supported by the Swedish Council for Working Life and Social Research.

\section{References}

[1] Thornicroft, G., Rosem D. and Kassam, A. (2007) Discrimination in Health Care against People with Mental Illness. International Review of Psychiatry, 19, 113-122. http://dx.doi.org/10.1080/09540260701278937

[2] Angermeyer, M.C. and Dietrich, S. (2006) Public Beliefs about and Attitudes towards People with Mental Illness: A Review of Population Studies. Acta Psychiatrica Scandinavica, 113, 163-179. http://dx.doi.org/10.1111/j.1600-0447.2005.00699.x

[3] Schomerus, G., Schwahn, C., Holzinger, A., Corrigan, P.W., Grabe, H.J., Carta, M.G. and Angermeyer, M.C. (2012) Evolution of Public Attitudes about Mental Illness: A Systematic Review and Meta-Analysis. Acta Psychiatrica Scandinavica, 125, 440-452. http://dx.doi.org/10.1111/j.1600-0447.2012.01826.x

[4] Livingston, J.D. and Boyd, J.E. (2010) Correlates and Consequences of Internalized Stigma for People Living with Mental Illness: A Systematic Review and Meta-Analysis. Social Science \& Medicine, 71, 2150-2161. http://dx.doi.org/10.1016/j.socscimed.2010.09.030

[5] Rüsch, N., Angermeyer, M.C. and Corrigan, P. (2005) Mental Illness Stigma. Concepts, Consequences and Initiatives to Reduce Stigma. European Psychiatry, 20, 529-539. http://dx.doi.org/10.1016/j.eurpsy.2005.04.004

[6] Sharac, J., McCrone, P., Clement, S. and Thornicroft, G. (2010) The Economic Impact of Mental Health Stigma and Discrimination: A Systematic Review. Epidemiologia e Psichiatria Sociale, 19, 223-232. http://dx.doi.org/10.1017/S1121189X00001159

[7] Gulliver, A., Griffiths, KM. and Christensen, H. (2010) Perceived Barriers and Facilitators to Mental Health HelpSeeking in Young People: A Systematic Review. BMC Psychiatry, 10, 113. http://dx.doi.org/10.1186/1471-244X-10-113

[8] Andrews, G., Henderson, S. and Hall, W. (2001) Prevalence, Co-Morbidity, Disability and Service Utilisation. Over- 
view of the Australian National Mental Health Survey. British Journal of Psychiatry, 178, 145-153. http://dx.doi.org/10.1192/bjp.178.2.145

[9] Sirey, J.A., Bruce, M.L., Alexopoulus, G.S., Perlick, D.A., Raue, P., Friedmann, S.J. and Meyers, B.S. (2001) Perceived Stigma as a Predictor of Treatment Discontinuation in Young and Older Outpatients with Depression. American Journal of Psychiatry, 158, 479-481. http://dx.doi.org/10.1176/appi.ajp.158.3.479

[10] Crisp, A.H., Gelder, A.G., Rix, S., Meltzer, H.I. and Rowlands, O.J. (2000). Stigmatisation of People with Mental Illnesses. British Journal of Psychiatry, 177, 4-7. http://dx.doi.org/10.1192/bjp.177.1.4

[11] Link, A.G., Phelan, J.C., Bresnahan, M., Stueve, A. and Pescosolido, B. (1999) Public Conceptions of Mental Illness: Labels, Causes, Dangerousness and Social Distance. American Journal of Public Health, 89, 1328-1333. http://dx.doi.org/10.2105/AJPH.89.9.1328

[12] Phelan, J.C. and Link, B.G. (1998) The Growing Belief That People with Mental Illnesses Are Violent: The Role of the Dangerousness Criterion for Civil Commitment. Social Psychiatry and Psychiatric Epidemiology, 33, 7-12. http://dx.doi.org/10.1007/s001270050204

[13] Dickerson, F.B., Sommerville, J., Origoni, A.E., Ringel, N.B. and Parente, F. (2002) Experiences of Stigma among Outpatients with Schizophrenia. Schizophrenia Bulletin, 28, 143-155.

http://dx.doi.org/10.1093/oxfordjournals.schbul.a006917

[14] Mann, C.E. and Himelien, M.J. (2004) Factors Associated with Stigmatization of Persons with Mental Illness. Psychiatric Services, 55, 185-187. http://dx.doi.org/10.1176/appi.ps.55.2.185

[15] Schulze, B. (2007) Stigma and Mental Health Professionals: A Review of the Evidence on an Intricate Relationship. International Review of Psychiatry, 19, 137-155. http://dx.doi.org/10.1080/09540260701278929

[16] Lauber, C., Nordt, C., Braunschweig, C. and Rössler, W. (2006) Do Mental Health Professionals Stigmatize Their Patients? Acta Psychiatrica Scandinavica, 113, 51-59. http://dx.doi.org/10.1111/j.1600-0447.2005.00718.x

[17] Nordt, C., Rössler, W. and Lauber, C. (2006) Attitudes of Mental Health Professionals towards People with Schizophrenia and Major Depression. Schizophrenia Bulletin, 32, 709-714. http://dx.doi.org/10.1093/schbul/sbj065

[18] Björkman, T., Angelman, T. and Jönsson, M. (2008) Attitudes towards People with Mental Illness: A Cross-Sectional Study among Nursing Staff in Psychiatric Care and Somatic Care. Scandinavian Journal of Caring Sciences, 22, 170177. http://dx.doi.org/10.1111/j.1471-6712.2007.00509.x

[19] Brinn, F. (2000) Patients with Mental Illness: General Nurses’ Attitudes and Expectations. Nursing Standard, 14, 3236. http://dx.doi.org/10.7748/ns2000.03.14.27.32.c2792

[20] Liggins, J. and Hatcher, S. (2005) Stigma toward the Mentally Ill in the General Hospital: A Qualitative Study. General Hospital Psychiatry, 27, 359-364. http://dx.doi.org/10.1016/j.genhosppsych.2005.05.006

[21] Schulze, B. and Angermeyer, M.C. (2003) Subjective Experiences of Stigma. A Focus Group Study of Schizophrenic Patients, Their Relatives and Mental Professionals. Social Science \& Medicine, 56, 299-321. http://dx.doi.org/10.1016/S0277-9536(02)00028-X

[22] Schulze, B., Richter-Werling, M., Matschinger, H. and Angermeyer, M.C. (2003) Crazy? So What! Effects of a School Project on Students’ Attitudes towards People with Schizophrenia. Acta Psychiatrica Scandinavica, 107, 142-150. http://dx.doi.org/10.1034/j.1600-0447.2003.02444.x

[23] Economou, M., Louki, E., Peppou, L.E., Gramandani, C., Yotis, L. and Stefanis, C.N. (2012) Fighting Psychiatric Stigma in the Classroom: The Impact of an Educational Intervention on Secondary School Students' Attitudes to Schizophrenia. International Journal of Social Psychiatry, 58, 544-551. http://dx.doi.org/10.1177/0020764011413678

[24] Serafini, G., Pompili, M., Haghighat, R., Pucci, D., Pastina, M., Lester, D., Angeletti, G., Tatarelli, R. and Girardi, P. (2011) Stigmatization of Schizophrenia as Perceived by Nurses, Medical Doctors, Medical Students and Patients. Journal of Psychiatric and Mental Health Nursing, 18, 576-585. http://dx.doi.org/10.1111/j.1365-2850.2011.01706.x

[25] Linden, M. and Kavanagh, R. (2012) Attitudes of Qualified vs. Student Mental Health Nurses towards an Individual Diagnosed with Schizophrenia. Journal of Advanced Nursing, 68, 1359-1368. http://dx.doi.org/10.1111/j.1365-2648.2011.05848.x

[26] Volmer, D., Mäesalu, M. and Bell, J.S. (2008) Pharmacy Students’ Attitudes toward and Professional Interactions with People with Mental Disorders. International Journal of Social Psychiatry, 54, 402-413. http://dx.doi.org/10.1177/0020764008090427

[27] Corrigan, P.W., Green, A., Lundin, R., Kubiak, M.A. and Penn, D.L. (2001) Familiarity with and Social Distance from People Who Have Serious Mental Illness. Psychiatric Services, 52, 953-958. http://dx.doi.org/10.1176/appi.ps.52.7.953

[28] Svensson, B., Markström, U., Bejerholm, U., Björkman, T., Brunt, D., Eklund, M., Hansson, L., Leufstadius, C., Gyllensten, A.L., Sandlund, M. and Östman, M. (2011) Test-Retest Reliability of the Swedish Version of Two Instruments for Measuring Public Attitudes towards Persons with Mental Illness. BMC Psychiatry, 11, 11. 
http://dx.doi.org/10.1186/1471-244X-11-11

[29] Watson, A.C., Corrigan, P.W. and Ottati, V. (2004) Police Officers' Attitudes toward and Decisions about Persons with Mental Illness. Psychiatric Services, 55, 49-53. http://dx.doi.org/10.1176/appi.ps.55.1.49

[30] Cotton, D. (2004) The Attitudes of Canadian Police Officers toward the Mentally Ill. International Journal of Law and Psychiatry, 27, 135-146. http://dx.doi.org/10.1016/j.ijlp.2004.01.004

[31] Corrigan, P.W., Edwards, A.B., Green, A., Diwan S.L. and Penn D.L. (2001) Prejudice, Social Distance and Familiarity with Mental Illness. Schizophrenia Bulletin, 27, 219-225. http://dx.doi.org/10.1093/oxfordjournals.schbul.a006868 
Scientific Research Publishing (SCIRP) is one of the largest Open Access journal publishers. It is currently publishing more than 200 open access, online, peer-reviewed journals covering a wide range of academic disciplines. SCIRP serves the worldwide academic communities and contributes to the progress and application of science with its publication.

Other selected journals from SCIRP are listed as below. Submit your manuscript to us via either submit@scirp.org or Online Submission Portal.
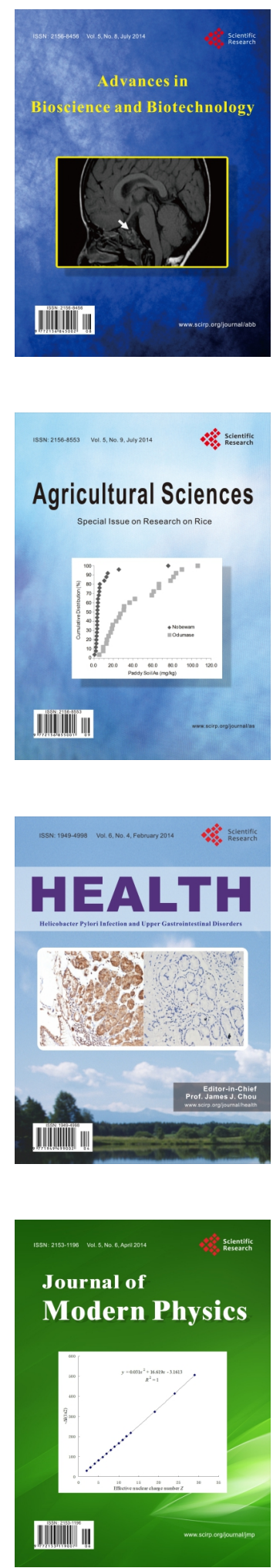
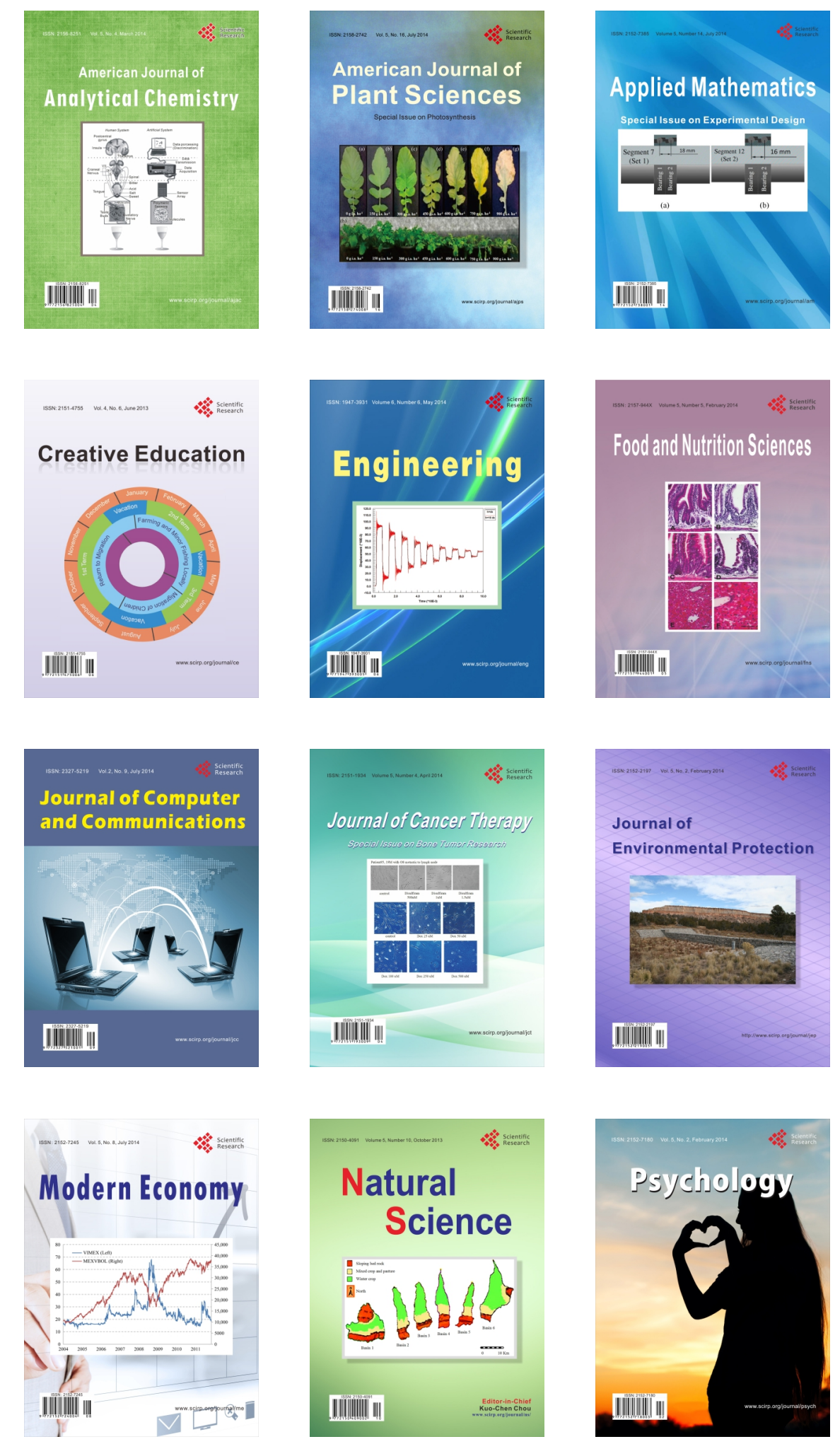